Original Article

\title{
FORMULATION DEVELOPMENT AND EVALUATION OF FAST DISSOLVING FILMS OF EBASTINE
}

\section{TEJASVI TORGAL, SHWETA BORKAR, PRASHANT BHIDE, ASMITA ARONDEKAR}

Goa College of Pharmacy, $18^{\text {th }}$ June Road, Panaji, Goa 403001, India

Email: swe_bha26@rediffmail.com

Received: 13 Jun 2020, Revised and Accepted: 16 Aug 2020

\section{ABSTRACT}

Objective: To overcome the limitations of fast dissolving tablets, a novel fast dissolving film of ebastine was formulated for attaining quick onset of action, aiding in the enhancement of bioavailability favorable in severe conditions of allergies.

Methods: Films of ebastine were prepared by the solvent casting method using hydroxypropyl methylcellulose E-15, hydroxypropyl methylcellulose $\mathrm{K}-4$ as a film base with different concentrations of crospovidone as superdisintegrant and polyethylene glycol-400 as a plasticizer. Further physical characteristics such as uniformity of weight, thickness, and drug content uniformity, tensile strength, folding endurance, percentage elongation, surface $\mathrm{pH}$, disintegration and in vitro drug release were evaluated.

Results: The optimized formulations with film base hydroxypropyl methylcellulose E-15 and hydroxypropyl methylcellulose K-4 containing 8\% crospovidone showed $99.34 \%$ and $97.42 \%$ of maximum cumulative percentage release respectively exhibiting first order kinetics. However, no significant change was observed in stability studies.

Conclusion: The concept of formulating fast dissolving films of ebastine offers a suitable approach in exhibiting rapid onset of action with improved delivery.

Keywords: Ebastine, Fast dissolving films, Hydroxypropyl methylcellulose, Crospovidone, In vitro dissolution studies

C) 2020 The Authors. Published by Innovare Academic Sciences Pvt Ltd. This is an open access article under the CC BY license (http://creativecommons.org/licenses/by/4.0/) DOI: http://dx.doi.org/10.22159/ijcpr.2020v12i5.39782. Journal homepage: https://innovareacademics.in/journals/index.php/ijcpr

\section{INTRODUCTION}

Recently, fast dissolving films (FDF), a more advanced drug delivery system have started gaining popularity and acceptance as new drug delivery systems, which aim to enhance the rapid onset of action to provide the drug molecule in a more convenient dosage form of administration and patient compliance formulation [1].

Allergic manifestation is quite uneasy and requires immediate medical treatment, thus the delivery system has to show the rapid onset of action which except for fast dissolving tablets (FDT), no other drug delivery system shows. FDT though shows advantages over other conventional forms in terms of rapid onset of action and better patient compliance, it has limitations like fear of swallowing and choking expensive manufacturing processes storage, handling and stability issues. Additionally, due to taste masking of a bitter drug in FDF, colors and flavors available in FDF's, this formulation gives a better consumer and aesthetic appeal than any other dosage form $[2,3]$.

Histamine is a key mediator in the development of allergy symptoms and oral $\mathrm{H} 1$ antihistamines are among the most widely used treatment for symptomatic relief in conditions such as allergic rhinitis and chronic idiopathic urticaria [4]. Ebastine is a second-generation longlasting and selective $\mathrm{H} 1$ histamine receptor antagonist which is an effective treatment for both seasonal and perennial allergic rhinitis and chronic idiopathic urticaria. Ebastine provides efficacy throughou the $24 \mathrm{~h}$ dosing interval with once-daily administration and clinical benefit are seen from the first day of treatment. It is rapidly absorbed after oral administration and undergoes extensive hepatic and intestinal first-pass metabolism $[5,6]$.

Their conventional tablet available in the market has a major drawback of less onset of action, which is required in the patients with allergic conditions. Hence, for an antihistaminic drug-like ebastine, we aimed to develop a quick disintegrating dosage form, thus exhibiting rapid relief from allergic conditions.

\section{MATERIALS AND METHODS}

\section{Materials}

Ebastine was a gift sample from Microlabs Ltd., Verna-Goa Hydroxypropyl methylcellulose (HPMC) E-15 and hydroxypropyl methylcellulose (HPMC) K-4 (Colorcon Asia Ltd, Goa), Crospovidone (Signet chem, Mumbai), aspartame (Dr. Reddy's, Hyderabad) carmoisine (Magnildye chem, Mumbai) and strawberry flavor (Sworld flavours and fragrances, Bengaluru) were received as gift sample. All the other chemicals used in analytical grade were procured from Lobacheme Pvt. Ltd, Mumbai.

\section{Methods}

\section{Preformulation studies}

The identification of the drug was carried out by Fourier Transform Infrared spectroscopy (FTIR) (Shimadzu, UV 2700). The purity of the drug was found out by the melting point determination by the open capillary method. Standardization of the drug was carried out using a UV spectrophotometer (Labindia UV 3092). Drug-excipient compatibility was assessed by Differential Scanning Calorimetry (DSC) (Shimadzu, DSC 60+) and FTIR spectral analysis

\section{Formulation of fast dissolving films}

In the present study, the fast-dissolving films of ebastine were prepared by a solvent casting method. The polymer solution was prepared using weighed quantities of polymers (table 1) and kept for swelling overnight in $4 \mathrm{ml}$ of distilled water. To this aqueous solution of polymer, plasticizer was added and stirred for 60 min on a magnetic stirrer covered with aluminum foil to prevent the loss of solvent. The drug solution was prepared using the appropriate quantity of drug and excipients in the remaining quantity of distilled water and ethanol. This drug solution was subjected to sonication for $20 \mathrm{~min}$ to ensure uniform dispersion of insoluble ingredients. After sonication, the polymer solution was added with continuous stirring for 7 to $8 \mathrm{~h}$ with aid of magnetic stirrer. One hour before casting the film, color and flavor were added to the final drugpolymer solution. Finally, after thorough mixing and dispersion, the drug-polymer solution was cast in a glass petri dish, $4 \mathrm{~cm}$ in diameter. Casted films were then subjected to drying in a vacuum oven at $40{ }^{\circ} \mathrm{C}$ for $24 \mathrm{~h}$. After drying, the casted film was slowly removed from petri dish and cut into films of $2 \times 2 \mathrm{~cm}$ in size and packed in laboratory prepared aluminium foil packages [7]. 


\section{Evaluation of fast dissolving films}

\section{General appearance}

The films were tested for size, shape, color, presence or absence of odor, surface texture, physical flaws, consistency and legibility of any recognizable markings.

\section{Drug content uniformity}

The drug content of the films was determined by dissolving the film of $2 \times 2 \mathrm{~cm}$ in $5 \mathrm{ml}$ of methanol and $20 \mathrm{ml}$ of $0.1 \mathrm{~N} \mathrm{HCl}$ in a $100 \mathrm{~m}$ volumetric flask. The mixture was sonicated for $10 \mathrm{~min}$ till the entire film dissolved and the final volume was made up by adding $0.1 \mathrm{~N}$ $\mathrm{HCl} .10 \mathrm{ml}$ of the resulting solution was diluted to $100 \mathrm{ml}$ with $0.1 \mathrm{~N}$ $\mathrm{HCl}$. Absorbance was measured at $257 \mathrm{~nm}$. Drug content was calculated according to the formula below

Drugcontent $=x \times \frac{100}{10} \times \frac{10}{100}$

" $\mathrm{x}$ " value was determined by substituting the obtained absorbance value in the equation of calibration curve concentration of dilution. Drug content was determined in triplicate for each formulation; mean and standard deviation was calculated [8].

Table 1: Composition of fast dissolving films

\begin{tabular}{|c|c|c|c|c|c|c|c|c|c|c|c|c|}
\hline \multicolumn{13}{|l|}{ Ingredients } \\
\hline Formulation & Ebastine & $\begin{array}{l}\text { HPMC } \\
\text { E-15 }\end{array}$ & $\begin{array}{l}\text { HPMC } \\
\text { K-4 }\end{array}$ & $\begin{array}{l}\text { PEG- } \\
400\end{array}$ & Crospovidone & $\begin{array}{l}\text { Tween- } \\
80\end{array}$ & $\begin{array}{l}\text { Citric } \\
\text { acid }\end{array}$ & Aspartame & Carmoisine & Strawberry & $\begin{array}{l}\text { Purified } \\
\text { water }\end{array}$ & Ethanol \\
\hline & (mg) & (mg) & (mg) & (ml) & (mg) & (ml) & (mg) & (mg) & (ml) & $(\mathrm{ml})$ & $(\mathrm{ml})$ & (ml) \\
\hline F1 & 125.7 & 500 & - & 0.2 & - & 0.3 & 20 & 40 & q. $s$ & 0.8 & 6 & 6 \\
\hline $\mathrm{F} 2$ & 125.7 & 450 & 50 & 0.2 & - & 0.3 & 20 & 40 & q. $s$ & 0.8 & 6 & 6 \\
\hline F3 & 125.7 & 500 & - & 0.2 & 30 & 0.3 & 20 & 40 & q. $s$ & 0.8 & 6 & 6 \\
\hline $\mathrm{F} 4$ & 125.7 & 500 & - & 0.2 & 40 & 0.3 & 20 & 40 & q. $\mathrm{s}$ & 0.8 & 6 & 6 \\
\hline F5 & 125.7 & 500 & - & 0.2 & 50 & 0.3 & 20 & 40 & q. $S$ & 0.8 & 6 & 6 \\
\hline F6 & 125.7 & 450 & 50 & 0.2 & 30 & 0.3 & 20 & 40 & q. $s$ & 0.8 & 6 & 6 \\
\hline F7 & 125.7 & 450 & 50 & 0.2 & 40 & 0.3 & 20 & 40 & q. $s$ & 0.8 & 6 & 6 \\
\hline F8 & 125.7 & 450 & 50 & 0.2 & 50 & 0.3 & 20 & 40 & q. $\mathrm{s}$ & 0.8 & 6 & 6 \\
\hline
\end{tabular}

\section{Weight variation}

A $2 \mathrm{~cm} \times 2 \mathrm{~cm}$ piece was cut from three different places of the cast film. Each film was weighed and weight variation was calculated. The mean with standard deviation was calculated.

\section{Thickness [9]}

The thickness of the film was measured by digital vernier caliper at three different strategic locations. It is essential to ascertain uniformity in the thickness of the film as this is directly related to the accuracy of the dose in the film. The mean with standard deviation was calculated.

\section{Tensile strength $[10,11]$}

The tensile strength was determined using tensile strength tester (laboratory designed) as shown in fig. 1. A $3 \mathrm{~cm} \times 1 \mathrm{~cm}$ film free from air bubbles or physical imperfections was held longitudinally in the tensile grip on the tester. The test was performed at $6 \mathrm{~mm}$ of initial grip separation. Weights were added to the pan till the film specimen broke. All measurements were performed in triplicate. The mean with standard deviation was calculated. It is calculated by the applied load at rupture divided by the cross-sectional area of the strip as given in the equation below:

Tensile strength $=\frac{\text { Losi af fallure }}{\text { Strip thickess X stripwidth }}$

Folding endurance $[8,12]$

Folding endurance is determined by repeated folding of the film at the same place until the film breaks. The number of times the film is folded without breaking is computed as the folding endurance value. The mean with standard deviation was calculated.

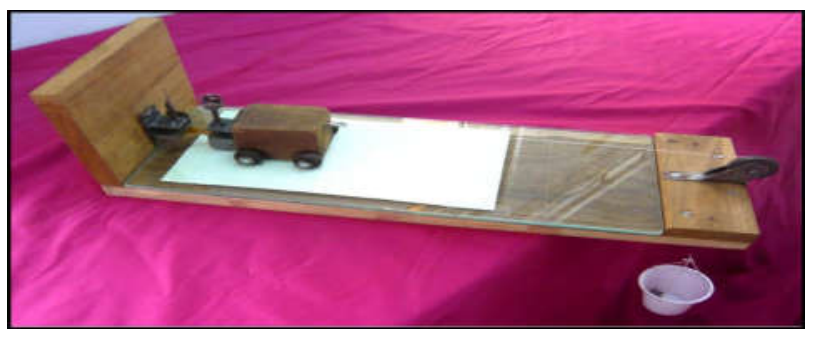

Fig. 1: Laboratory designed tensile strength tester

\section{Percent elongation [10]}

When stress is applied, a film sample stretches and this is referred to as a strain. A strain is the deformation of strip divided by the original dimension of the sample.

Percent elongation $=\frac{\text { Increase in length of strip } \times 100}{\text { Initial lengh sf strip }}$

\section{In vitro disintegration time [9]}

In vitro disintegration time was determined visually in a petri dish containing $10 \mathrm{ml}$ of $\mathrm{pH} 6.8$ phosphate buffer which mimicked the properties of simulated saliva. The disintegration time is noted as a time at which film disintegrates. Three readings were taken. The mean with standard deviation was calculated.

Surface pH $[13,14]$

The $\mathrm{pH}$ was measured using electrode $\mathrm{pH}$ meter, by making surface contact of the electrode with an oral film which was prior made slightly wet with water. The procedure was performed in triplicate and mean with standard deviation was reported.

\section{In vitro dissolution studies [15]}

In vitro dissolution studies were carried out using USP Type II (modified paddle type) dissolution apparatus. The dissolution was carried out in $900 \mathrm{ml}$ of $0.1 \mathrm{~N} \mathrm{HCl}$ maintained at $37.5 \pm 0.5^{\circ} \mathrm{C}$ at 50 $\mathrm{rpm}$. A 2 × $2 \mathrm{~cm}$ film (a size which contains unit dose) was cut from 
cast film and placed on a glass slide and covered with mesh to hold film sample in place. This was then placed at the bottom of the dissolution bowl. $5 \mathrm{ml}$ samples were taken at $2 \mathrm{~min}$ intervals till 10 $\mathrm{min}$, after that $5 \mathrm{ml}$ samples were taken every $5 \mathrm{~min}$ till $30 \mathrm{~min}$. The replenishing of the dissolution medium was done after each sample was withdrawn. The drug content was then determined spectrophotometrically at $\lambda_{\max }$ of $257 \mathrm{~nm}$ and drug release was calculated.

\section{Accelerated Stability studies [10, 16]}

Stability studies of optimized formulations were carried out as per ICH guidelines by storing the sample at $40{ }^{\circ} \pm 2{ }^{\circ} \mathrm{C} / 75 \% \pm 5 \% \mathrm{RH}$ for 30 d. Samples were analyzed for drug content, weight variation, thickness, tensile strength, surface $\mathrm{pH}$, disintegration time and in vitro dissolution studies.

\section{RESULTS}

\section{General appearance}

All the films were square, translucent to opaque, pink in color, with flat surfaces, and has a smooth texture. The size of the film was 20 $\mathrm{mm}$ in length and breadth, and there was an absence of any odor and physical flaws.

\section{Drug content uniformity}

Drug content uniformity results of all eight formulations are tabulated in table 2 . The percent drug content was observed to be in the range of $94.83 \pm 0.076-101.17 \pm 0.029 \%$ which are in the acceptable limits.

\section{Weight variation}

Weight variation results are shown in table 2 . Weights were observed in range of $0.057 \pm 0.001 \mathrm{mg}$ to $0.111 \pm 0.003 \mathrm{mg}$. Variation among different formulations was obtained which may be related to type and amount of polymer used.

\section{Thickness}

Thickness results are tabulated in table 2. Thickness is in range $0.095 \pm 0.004 \mathrm{~mm}$ to $0.177 \pm 0.003 \mathrm{~mm}$. Results indicate satisfactory thickness for oral administration.

\section{Tensile strength}

The results are shown in table 2. Tensile strengths range in $0.541 \pm 0.011 \mathrm{~kg} / \mathrm{mm}$ to $0.807 \pm 0.010 \mathrm{~kg} / \mathrm{mm}$. The values can be correlated to varied type and amount of polymer used in all formulations.

\section{Folding endurance}

The results are shown in table 2 . Folding endurance is in range $265.67 \pm 2.08$ to $322.33 \pm 2.52$. Results can be correlated to the type of polymers used.

\section{Percent elongation}

Percent elongation values are listed in table 2. Values range from $10.56 \pm 0.96 \%$ to $19.44 \pm 0.96 \%$. It can be correlated to the type and amount of polymers used.

\section{In vitro disintegration time}

The results are tabulated in table 3 . In vitro disintegration time values are in the range of $29.67 \pm 1.53 \mathrm{~s}$ to $121.33 \pm 0.58 \mathrm{~s}$. Results varied with type and amount of polymers and superdisintegrant. Formulation $F_{1}$ and $F_{2}$ showed the highest disintegration time i.e. $112.33 \mathrm{~s}$ and $121.33 \mathrm{~s}$ respectively as crospovidone was not added to these formulations. Disintegration time of optimized formulation i.e. $\mathrm{F}_{4}$ was $29.67 \mathrm{~s}$ in which only single polymer i.e. HPMC E-15 was used and $8 \% \quad(40 \mathrm{mg})$ crospovidone were used as a superdisintegrant (fig. 2). Disintegration time of second optimized formulation i.e. $\mathrm{F}_{7}$ was $34.67 \mathrm{~s}$ in which combination of polymers HPMC E-15, HPMC K-4 and 8\% (40 mg) Crospovidone was used. It is observed that disintegration time of the film with a base as HPMC E15 alone and films with a base as HPMC E-15 and HPMC K-4 in combination showed a decrease from 45 to $29.67 \mathrm{~s}$ and 50.66 to $34.67 \mathrm{~s}$ with an increase in the concentration of crospovidone from 6 to $8 \%$ respectively, further increase in the concentration of crospovidone increased the disintegration time possibly due to blockade of capillary pores which prevents the entry of fluid into the film.

Table 2: Evaluation of fast dissolving films

\begin{tabular}{llllll}
\hline $\begin{array}{l}\text { Formulation } \\
\text { code }\end{array}$ & $\begin{array}{l}\text { Percentage } \\
\text { drug content } \\
\text { (\%) mean } \pm \text { SD }\end{array}$ & $\begin{array}{l}\text { Weight } \\
\text { variation } \\
\text { (mg) mean } \pm \text { SD }^{*}\end{array}$ & $\begin{array}{l}\text { Thickness } \\
\text { (mm) } \\
\text { mean } \pm \text { SD }^{*}\end{array}$ & $\begin{array}{l}\text { Tensile strength } \\
\text { (kg/mm) } \\
\text { mean } \pm \text { SD }^{*}\end{array}$ & $\begin{array}{l}\text { Folding endurance } \\
\text { (No. of folds) } \\
\text { mean } \pm \text { SD }^{*}\end{array}$ \\
\hline F1 & $100.43 \pm 0.101$ & $0.057 \pm 0.001$ & $0.095 \pm 0.004$ & $0.571 \pm 0.011$ & $316.00 \pm 1.00$ \\
F2 & $94.83 \pm 0.076$ & $0.074 \pm 0.001$ & $0.159 \pm 0.004$ & $0.805 \pm 0.002$ & $278.33 \pm 3.06$ \\
F3 & $95.92 \pm 0.101$ & $0.061 \pm 0.001$ & $0.104 \pm 0.005$ & $0.552 \pm 0.021$ & $319.33 \pm 1.53$ \\
F4 & $101.08 \pm 0.014$ & $0.063 \pm 0.000$ & $0.112 \pm 0.004$ & $0.566 \pm 0.013$ & $322.33 \pm 2.52$ \\
F5 & $101.17 \pm 0.029$ & $0.066 \pm 0.000$ & $0.127 \pm 0.003$ & $0.541 \pm 0.011$ & $304.00 \pm 2.00$ \\
F6 & $99.00 \pm 0.125$ & $0.078 \pm 0.000$ & $0.154 \pm 0.003$ & $0.799 \pm 0.006$ & $290.67 \pm 2.89$ \\
F7 & $100.42 \pm 0.104$ & $0.095 \pm 0.001$ & $0.162 \pm 0.003$ & $0.807 \pm 0.010$ & $284.33 \pm 2.08$ \\
F8 & $98.67 \pm 0.113$ & $0.111 \pm 0.003$ & $0.177 \pm 0.003$ & $0.795 \pm 0.012$ & $265.67 \pm 2.08$ \\
\hline
\end{tabular}

*SD standard deviation 


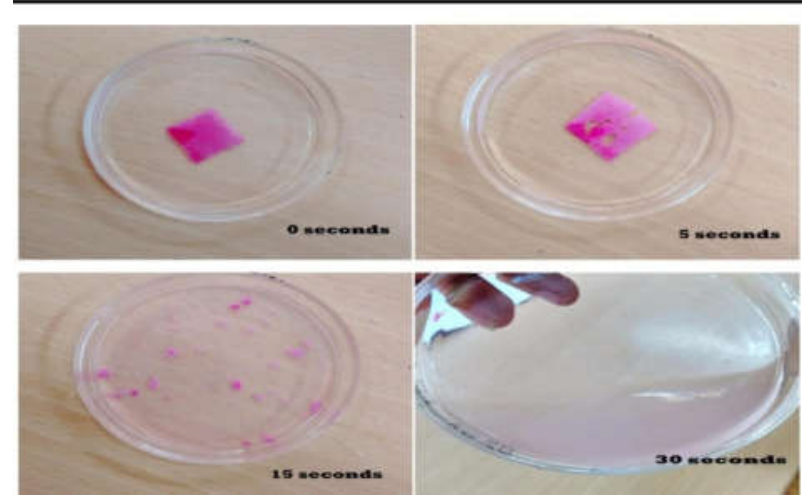

Fig. 2: In vitro disintegration study of formulation F4

\section{Surface pH}

The results are tabulated in table 3 . Surface $\mathrm{pH}$ values are in range $6.43 \pm 0.20$ to $6.87 \pm 0.03$. It is seen that surface $\mathrm{pH}$ values are close to neutral $\mathrm{pH}$ hence the risk of irritation to oral mucosa is reduced.

\section{In vitro dissolution studies}

All formulations were subjected to in vitro dissolution studies in 0.1 $\mathrm{N} \mathrm{HCl}$ using modified USP dissolution test apparatus type II. The amount of plasticizer used is the same for all formulations while type and amount of polymer are varied. Also the amount of superdisintegrant is varied or absent in some formulations. Thus release may be influenced by type and amount of polymer and amount of crospovidone. Results are tabulated in table 3 . At the end of $30 \mathrm{~min}$, drug release is approximately 89.55-99.34\% for all the formulations containing crospovidone as superdisintegrant $\left(\mathrm{F}_{3}\right.$ to $F_{8}$ ). Formulations $F_{1}$ and $F_{2}$ which do not contain crospovidone showed $68.62 \%$ and $58.18 \%$ cumulative drug release respectively at the end of $30 \mathrm{~min}$. Hence it is seen that the formulations in which crospovidone (superdisintegrant) was not added showed poor release than the ones in which crospovidone was added, this proves that crospovidone aided in better and faster release of the drug from the formulations in which it was added. Also, the amount of release was affected by the type and amount of polymer used, Formulation $F_{1}, F_{3}, F_{4}$ and $F_{5}$ with single HPMC E-15 base showed greater release than $F_{2}, F_{6}, F_{7}$ and $F_{8}$ which had the base of HPMC E-15 and HPMC K4. This proves that the type and amount of polymer also affected the release from all the formulations. The formulations prepared with HPMC E-15 alone as a film base with crospovidone as a superdisintegrant in the concentration of 6,8 and $10 \%$ showed $92.60,99.34$, and $95.01 \%$ respectively at the end of $30 \mathrm{~min}$. The formulations prepared with HPMC E-15 and HPMC K-4 in combination as a film base with crospovidone in the concentration of 6,8 and $10 \%$ showed $89.56,97.42$ and $92.46 \%$ respectively at the end of $30 \mathrm{~min}$. It is observed that drug release from the film increased from 92.6 to $99.34 \%$ and 89.56 to $97.42 \%$ with an increase in the concentration of crospovidone from 6 to $8 \%$ respectively, further increase in the concentration of crospovidone i.e. from 8 to $10 \%$ decreased the drug release due to the increase in disintegration time. Data were subjected to kinetic treatment to determine the release pattern. All the formulations can be best fitted in the first-order kinetics (fig. 3).

Table 3: Evaluation of fast dissolving films

\begin{tabular}{|c|c|c|c|}
\hline $\begin{array}{l}\text { Formulation } \\
\text { code }\end{array}$ & $\begin{array}{l}\text { In vitro disintegration time } \\
\text { (s) mean } \pm \mathrm{SD}^{*}\end{array}$ & Surface pH mean $\pm S D^{*}$ & $\begin{array}{l}\text { Percent cumulative drug release at end of } \\
30 \text { min mean } \pm \text { SD }^{*}\end{array}$ \\
\hline F1 & $112.33 \pm 1.53$ & $6.43 \pm 0.20$ & 68.623 \\
\hline F2 & $121.33 \pm 0.58$ & $6.74 \pm 0.04$ & 58.183 \\
\hline F3 & $45.00 \pm 1.00$ & $6.58 \pm 0.04$ & 92.606 \\
\hline $\mathrm{F} 4$ & $29.67 \pm 1.53$ & $6.78 \pm 0.03$ & 99.341 \\
\hline F5 & $37.67 \pm 1.53$ & $6.87 \pm 0.03$ & 95.014 \\
\hline F6 & $50.67 \pm 1.53$ & $6.86 \pm 0.05$ & 89.559 \\
\hline F7 & $34.67 \pm 0.58$ & $6.82 \pm 0.07$ & 97.417 \\
\hline F8 & $44.00 \pm 2.00$ & $6.86 \pm 0.04$ & 92.463 \\
\hline
\end{tabular}

*SD standard deviation 


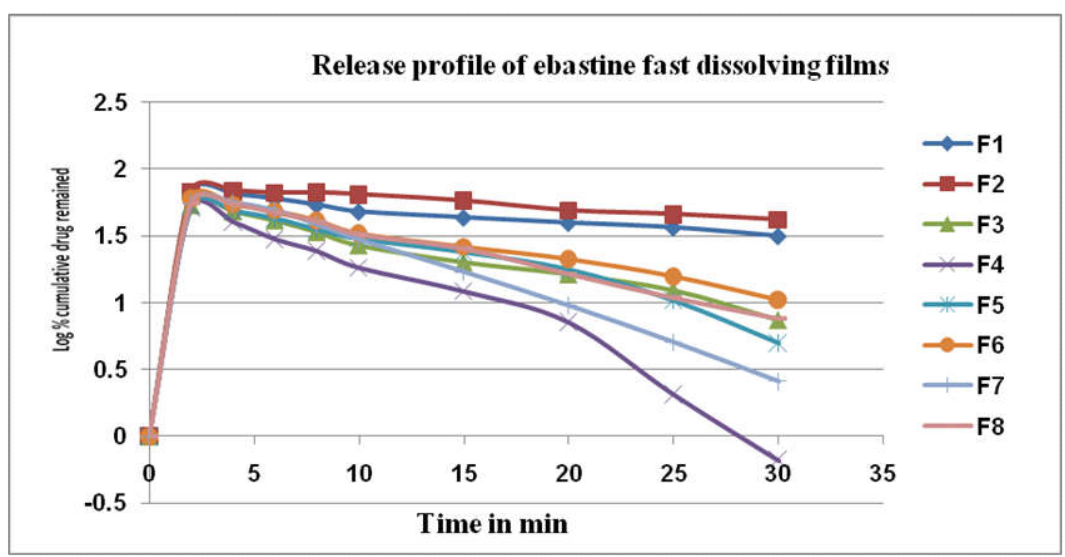

Fig. 3: In vitro release profile of ebastine fast dissolving films

\section{Accelerated stability studies}

The optimized formulations $\mathrm{F}_{4}$ and $\mathrm{F}_{7}$ were subjected to stability studies at $40{ }^{\circ} \mathrm{C} \pm 2{ }^{\circ} \mathrm{C} / 75 \pm 5 \% \mathrm{RH}$ for one month. Samples were analyzed for drug content, weight variation, thickness, tensile strength, surface $\mathrm{pH}$ and dissolution. No significant variation was found in the results of stability samples.

\section{DISCUSSION}

FDFs of ebastine were prepared by the solvent casting method using HPMC E-15 and HPMC K-4 as a film base with different concentrations of crospovidone as superdisintegrant and polyethylene glycol-400 (PEG-400) as a plasticizer. HPMC E-15 alone was used in four formulations while in the other four formulations a combination of HPMC E-15 and HPMC K-4 was used in the ratio of 9:1 respectively. As most of the excipients are soluble in water, it was used as one of the solvents for casting the films. Ebastine being insoluble in water but sparingly soluble in ethanol it was uniformly dispersed using the combination of water and ethanol as solvents. Ethanol also aided in quick uniform drying of the films as compared to the slow drying with only purified water used as a solvent during trials. The amount of both the solvents was also optimized in this process. Plasticizer was used in the formulation to improve the film properties. PEG-400 was used as a plasticizer and was tried at varied concentrations to observe its effect on film formation and film properties. Tween 80 was added as a surfactant. Crospovidone gave better films with good disintegration properties. Thus crospovidone was used as a superdisintegrant which aided in a faster dissolution of films within seconds and quick release of an active agent. The effect of varied concentrations of crospovidone on the disintegration time of the film and drug release was also observed. The amount of drug to be added to the casting solution was determined by considering dose per unit film, the surface area of film and that of petri dish. The drug content of films was determined and the amount of drug to be added to casting the film was optimized. Acceptability of orally disintegrating or dissolving formulations largely depends on its aesthetic appeal and taste perceived in the mouth as the formulation disintegrates or dissolves before it is swallowed. Thus, strawberry flavor, carmoisine color and aspartame as sweetener were used in the formulation. On the interpretation of data obtained from physicochemical evaluation and in vitro dissolution studies, it was found that formulation $\mathrm{F}_{4}$ and $\mathrm{F}_{7}$ gave the best results among all others and hence were considered as optimized formulations in their respective polymer base to provide the drug in the more convenient and patient compliant formulation.

\section{CONCLUSION}

Collectively from the results obtained, it is revealed that the fastdissolving films of ebastine can be considered suitable for clinical use in the treatment of allergic rhinitis and other conditions of allergies, where a quicker onset of action for a dosage form is desirable along with the convenience of administration [11]. The data demonstrated that 8\% crospovidone with HPMC E-15 alone or in combination with HPMC K-4 as a film base was suitable for developing fast dissolving films of ebastine. Conclusively, the current study attained in successfully designing and evaluating the drug delivery system. Being a consumer-friendly alternative, switching the product franchise from oral disintegrating tablet to fast dissolving film provides a good platform for product non-infringing product development. Drug formulation technology is a good tool for product life cycle management for increasing the patent life of existing molecules or products.

\section{ACKNOWLEDGEMENT}

The authors are grateful to Microlabs Ltd., Verna Goa for providing gift sample of drug ebastine, Colorcon Asia Ltd., Goa for gifting HPMC E-15LV and HPMC K-4, Signet chem., Mumbai for supplying crospovidone, Dr. Reddy's, Hyderabad for providing Aspartame. Magnil Dye chem., Mumbai and S world flavours and Fragnances, Bengaluru for gifting other excipients. Authors are also thankful to Chemistry Department, Goa University for providing the necessary facilities to carry out the study and using Quality Control instruments.

\section{FUNDING}

Nil

\section{AUTHORS CONTRIBUTIONS}

All the authors have contributed equally.

\section{CONFLICT OF INTERESTS}

The authors declare that there is no conflict of interest regarding the publication of this paper.

\section{REFERENCES}

1. Revathi V. Fast dissolving drug delivery system. Pharma Times 2007;39:22-3

2. Kaur M, Rana AC, Seth N. Fast dissolving films: an innovative drug delivery system. Int J Pharm Res Allie Sci 2013;2:14-24.

3. Gupta P, Bisht A, Rao NGR. Fast dissolving oral films: a comprehensive review. World J Pharm Res 2019;5:116-27.

4. Mishra R, Amin A. Formulation and characterization of rapidly dissolving films of cetirizine hydrochloride using pullulan as a film-forming agent. Ind J Pharm Edu Res 2011;45:71-7.

5. Ebast. Available from: http://www.unitedpharmacies.com/Ebast-ebastine.html [Last accessed on 05 Sep 2014

6. Ebastine Pharmacology https://www.medicineindia.org/pharmacology-forgeneric/1145/ebastine [Last accessed on 04 Sep 2014] 
7. Saini P, Kumar A, Sharma P, Visht S. Fast disintegrating oral films: a recent trend of drug delivery. Int J Drug Dev Res 2012;4:80-94.

8. Nafee NA, Boraie MA, Ismail FA, Mortada LM. Design and characterization of mucoadhesive buccal patches containing cetylpyridinium chloride. Acta Pharm 2003;53:199-212.

9. Reddy U, Reddy S, Katta M, Thyagaraju K. A detailed review of fast dissolving oral films. Indo Am I Pharm Res 2018:8:1351 26.

10. Cilurzo F, Minghetti P, Como A, Montanari L. Maltodextrin fast dissolving film: a feasibility study. Eur J Pharm Biopharm 2008;70:895-900.

11. Roshan B, Ravindranath S. Osteoarthritis: pathophysiology and current treatment modalities. J Drug Delivery Ther 2019;9:661-8.
12. Lakshmi PK, Malavika P, Vidya K. Formulation and evaluation of oral films of atomoxetine hydrochloride. Int Res J Pharm 2018;9:105-9.

13. Kumar GV, Krishna RV, William GJ, Konde A. Formulation and evaluation of buccal films of salbutamol sulphate. Ind J Pharm Sci 2005;67:160-4

14. Mashru RC, Sutariya VB, Sankalia MG, Parikh PP. Development and evaluation of fast dissolving film of salbutamol sulphate. Drug Dev Ind Pharm 2005;31:25-34

15. Bagul Uddhav, Gujar Kishore, Patel Nancy, Sanjeevani Aphale Shalaka Dhat. Formulation and evaluation of sublimed fast melt tablets of levocetirizine dihydrochloride. Int J Pharm Sci 2010;2:76-80.

16. Zankhana Patel, Rahil Bhura, Samir Shah. Formulation optimization and evaluation of mouth dissolving film of ramosetron hydrochloride. Int J Curr Pharm Sci 2020;12:99105 